\title{
超臨界水酸化処理技術を利用した有機廃寨物処理*
}

\author{
オルガノ株式会社 SCWO 部 大 江 太 郎
}

\section{Waste Water Treatment by Supercritical Water Oxidation}

Taro Oe

Organo Corporation SCWO Department

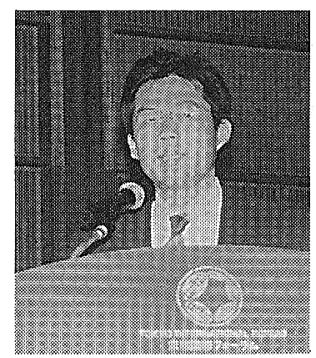

Supercritical water (over 374 centigrade and $22 \mathrm{MPa}$ ) has so high solubility for organic and oxygen that they are consist in homogeneous phase. So it is very easy to oxidize organic compounds. Further more, in supercritical water it is occurred that hydrolysis and pyrolysis, so scwo (supercritical water oxidation) process has high decomposition ability for organic compounds.

We have already operated the scwo pilot-scale plant based on MODAR technology which has the capacity of up to 2 ton/day since 1995. Using this plant, we have demonstrated to decompose various chemicals safely and completely. In the case of DMSO (dimethyl surfoxide), decomposition rate efficiency is over $>99.999 \%$. Furthermore, we have demonstrated PCBs of up to 7 wt \% and sewage sludge decomposition by a benchscale plant. In the case of PCBs, it is important to analyze by-products. We analyzed dioxines and co-PCBs to confirm complete decomposition. On the other hand, in the case of sewage sludge, the decomposition ability of nitrogen components is important. Over 600 centigrade we confirmed that nitrogen components change to nitrogen gas.

Keywords: supercritical water oxidation, waste, DMSO, PCB, sewage sludge, dioxine

\section{1. 緒言}

有機廃棄物による環境そして人体への污染が仜惧さ れるようになって久しいが，法規制においても現害に 整備が行われ，その扱いと処理には十分な注意が必要 となってきている。国際的な規制としては,バーゼル 条約とロンドン条約があり，前者は有害有機物への移 動を禁止するため 1989 年に採択され，後者は陸上で 発生した廃棄物の海洋投棄ならびに洋上での焼却処理

*平成 9 年度年次大会講演（講演 No.B 2-22）
を禁止したものである。一方，国内においては，1992 年に廃棄物の処理抢よび清掃に関する法律が改正され， 1993 年には環境基本法が制定されている。このように, 国内外において，有害有機物への規制が強まり，環境 に対する負荷の少ない処理が必要とされている。

通常, 有機物の処理としては, 焼却法がもつとも一 般的である。この技術は, 高い分解率が得られるが, 何らかの外因により，多イオキシンに代表される副生 成物を生じた場合，その物質は大気へ放出されるため， 回収は事実上，不可能である。特に，有害有機物を処 理する場合には高分解能力とクローズド性が要求され 
るため，焼却処理は必ずしも最適な処理とは言い難い。 それに対し, 超臨界水酸化は処理物質が水中に存在す るため，モニタリング後に系外へ排出することとなり， きわめて，クローズド性の高い処理といえる。

\section{2. 水の物性・超臨界水の物性}

超臨界水酸化は, 臨界点以上の水の特異的な性質を 用いる。表 1 に気体，超臨界流体および液体の一般的 な物性を示す。

このように，超臨界流体は，液体なみの密度を持ち ながら粘度, 拡散係数においては気体に近い流体であ ることがわかる。この傾向は超臨界水においても同様 であるため, 超臨界水は液体のような溶解力と気体の ような激しい分子運動をあわせもった流体といえる。 また，超臨界水では温度・圧力を制御することにより， これらの物性のほかに誘電率やイオン積もある範囲で コントロールできる。誘電率は溶質を選択する支配的

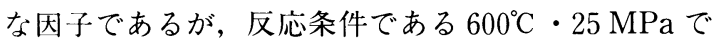
は誘電率は 2 と室温の水の 80 に対し，極めて低い。 その結果, 超臨界水では有機物等の非極性物質への溶 解能力は極就くなる。また，空気や酸素といった 気体とは均一相を形成するため, 有機物の酸化を行う 上で，超臨界水は優れた反応溶媒となる ${ }^{2)}$ 。

\section{3. 超臨界水酸化とは}

分解对象物質となる有機物と酸化剤がその場におい て完全に相互溶解しあうことが大前提である。超臨界 水はそれが実現できる場の一つなのであるとともに， 有機溶媒とは違い，きわめて環境に対し優しい物質 (ただの水) である。通常, 酸化分解の対象になる物 質は有機物であるが, 私たちが知っている水（常温・ 常圧の水〜亜臨界水）はこれらの物質のうち多くのも のを溶解できない（水と油の関係である)。また, 酸 化剂として用いられる空気等のガスに対する溶解度も 僅かである。よって，亜臨界水を反応場として用いる
と，その溶解度の低さから拡散律速となってしまい, 反応速度が遅くなる。それに対し, 超臨界水は有機物, ガスともに相互溶解するため拡散律速となることがな い。この超臨界水が持つ溶解特性は, 超臨界水の密度 と誘電率（図 1) から説明がなされる。一般に, 密度 と誘電率はその物質の溶解性を示す物性として知られ ており, 高密度のものほど溶解性が高く, 誘電率の小 さいものほど非極性物質を溶解する。常温常圧下の水 では, 密度 $1 \mathrm{~g} / \mathrm{cm}^{3}$, 誘電率約 80 なのに対し, $400^{\circ} \mathrm{C}$, $35 \mathrm{MPa}$ の超臨界水は密度 $0.47 \mathrm{~g} / \mathrm{cm}^{3}$, 誘電率は 10 , 同じ圧力で温度を $500^{\circ} \mathrm{C}$ とすると, 密度 $0.14 \mathrm{~g} / \mathrm{cm}^{3}$, 誘電率は約 2 と小さくなる。その結果, 超臨界水はべ ンゼンのような非極性物質も完全に溶解することがで きるとともに，酸素等のガスと任意の割合で混合する。 このように，有機物の酸化分解を行う場として優れた 物性を持つ超臨界水であるが，注意しなければならな いことがある。それは，超臨界水の低い誘電率下では イオン種の多くはイオン対として存在することになり， 無機物の溶解度が亜臨界水と比べきわめて低いことで ある。例之ば，常温常圧下の水は， $\mathrm{NaCl}$ に対し約 26 $\%$ の溶解度を持っているのに対し， $500^{\circ} \mathrm{C} ・ 25 \mathrm{MPa}$ の超臨界水には約 $100 \mathrm{ppm}$ 溶解するだけである。

上記のような性質を持つ超臨界水中での酸化反応は 次のように起こる。

Organic Compounds $+\mathrm{O}_{2}$

$$
\rightarrow \mathrm{CO}_{2}+\mathrm{H}_{2} \mathrm{O}
$$

Organic Hereroatoms

$\rightarrow$ Acids, Salts, Oxides

Acids $+\mathrm{NaOH}$

$\rightarrow$ Inorganic Salts

有機塩素化合物は分解により, 塩素は塩化物イオン となり，多イオキシンに代表される有害な副生成物を 生じない。同様に，窒素は硝酸，覀硝酸イオンもしく は窒素ガスとして, 硫黄は, 硫酸イオンとしてふるま うため, $\mathrm{NO}_{\mathrm{x}}$ や $\mathrm{SO}_{2}$ を生じず，焼却法では必要とな

表 1 超臨界流体の一般的な特性 ${ }^{11}$

\begin{tabular}{c|c|c|c}
\hline & 密度 $\left[\mathrm{g} / \mathrm{cm}^{3}\right]$ & 粘度 $[\mathrm{P}]$ & 拡散係数 $\left[\mathrm{cm}^{2} / \mathrm{s}\right]$ \\
\hline $\begin{array}{c}\text { 気 体 } \\
\text { (常温・常圧) }\end{array}$ & $(0.6 \sim 2.0) \times 10^{-3}$ & $(1 \sim 3) \times 10^{-4}$ & $0.1 \sim 0.4$ \\
\hline $\begin{array}{c}\text { 超臨界流体 } \\
\text { (臨界点近傍) }\end{array}$ & $0.2 \sim 0.5$ & $(1 \sim 3) \times 10^{-4}$ & $0.7 \times 10^{-3}$ \\
\hline $\begin{array}{c}\text { 液 体 } \\
\text { (常温・常圧) }\end{array}$ & $0.6 \sim 1.6$ & $(0.2 \sim 3) \times 10^{-2}$ & $(0.2 \sim 3) \times 10^{-5}$ \\
\hline
\end{tabular}




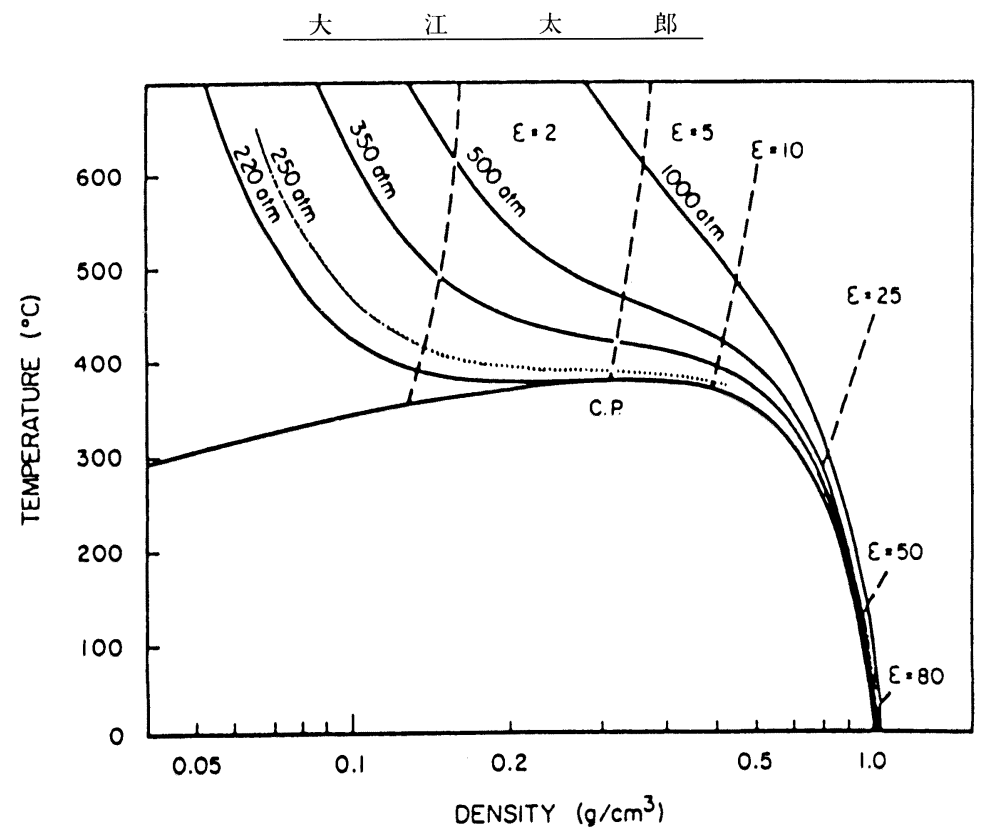

図 1 密度と誘電率の関係

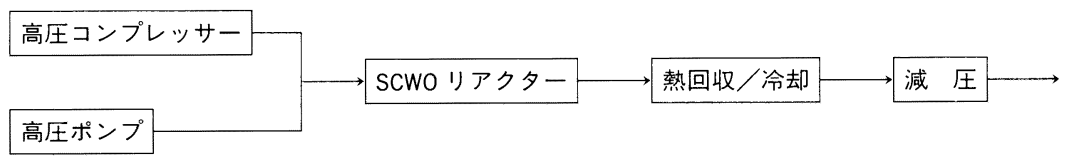

図 2 チューブリアクター使用システム

る排ガス処理施設を要しない。この特徴は, 装置のコ ンパクト化を行うにあたり非常に有効である。

この超臨界水酸化の実用化はアメリカの MODAR 社によりはじめられ, 数々の有機物が定量下限值以下 まで分解できることを証明している。その代表的な物 質を表 2 に示す。

このように高い分解能力を持つ超臨界水酸化のシス テム構成はリアクター構造により大きく次の 2 つに分 類される。

\section{1 チューブリアクタータイプ (図 2)}

流通式リアクターを用いたこの反応器の最大の特徵 はその単純さである。塩を生成しない物質の分解には 使用できるが, 塩が生成される場合, 反応器内で析出 し，閉塞を起こす。

\section{2 ベッセルリアクタータイプ}

本リアクターの特徵は, 単一反応器内で超臨界領域 と严臨界領域の 2 ゾーンを形成することにある。高濃 度の塩を生成する条件にも対応できる事が最大の特徵 である。詳細については次項のパイロットプラント実 証研究の項で述べる。
表 2 有機塩素化合物の分解結果（オルガノ侏㧍よび 米国：MODAR 実施) ${ }^{3) \sim 71}$

反応条件： $600^{\circ} \mathrm{C}, 25 \mathrm{MPa}$, 数分

\begin{tabular}{c|c}
\hline 物 質 名 & 分 解 率 $[\%]^{\text {it) }}$ \\
\hline ダイオキシン & $>99.9999$ \\
\hline クロロトルエン & $>99.998$ \\
\hline クロロフェノール & $>99.99$ \\
\hline DDT & $>99.997$ \\
\hline 四塩化炭素 & $>99.53$ \\
\hline PCBs & $>99.99999$ \\
\hline $1,1,1$-トリクロロエタン & $>99.9999$
\end{tabular}

注）いずれの物質も定量下限值まで分解

\section{4. パイロットプラントによる実証研究}

超臨界水は, 酸化分解, 熱分解そして加水分解によ り，有機物を分解する方法であり，極めて高い分解率 が得られるが，八ロゲンを含む有機物を分解すると， 酸を生じ, そのため, 反応器への腐食が著しい。そこ 


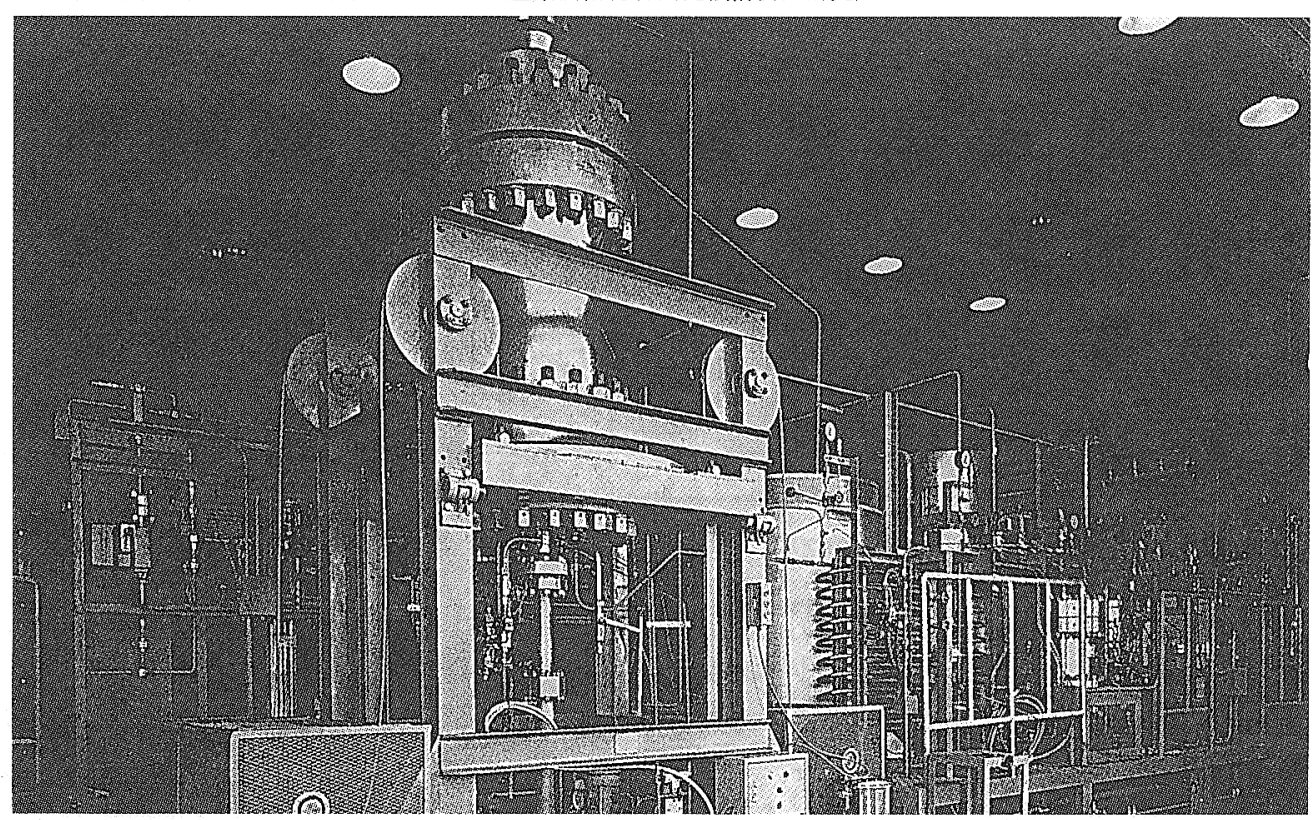

写真 1 パイロットプラント全景（オルガノ株式会社総合研究所内：NEDO 受託研究 H 7〜9 年度)

で，腐食を抑えるため，中和を行う必要があるが，上 述の反応式にあるように，無機塩を生成する。この無 機塩等，極性物質の超臨界水への溶解能力はその誘笪

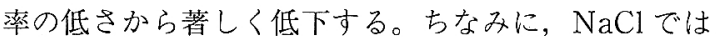
室温では $25 \mathrm{wt} \%$ 溶解するのに対し，この条件下では， 約 $100 \mathrm{ppm}$ 溶解するのみである5。

そこで反応生成物としての無機塭が固形物として析 出するという問題点が生じる。この塩の圧力容器から の排出が実装置化へ向けての大きなブレータスルーポ イントである。この壏の連続的な排出が可能な反応器 が, 現在, 実証研究を行っているベッセルリアクター 方式である。本プロセスのフローを図 3 に示す。

このパイロットプラントは $10 \%$ の炭素を含む廃液

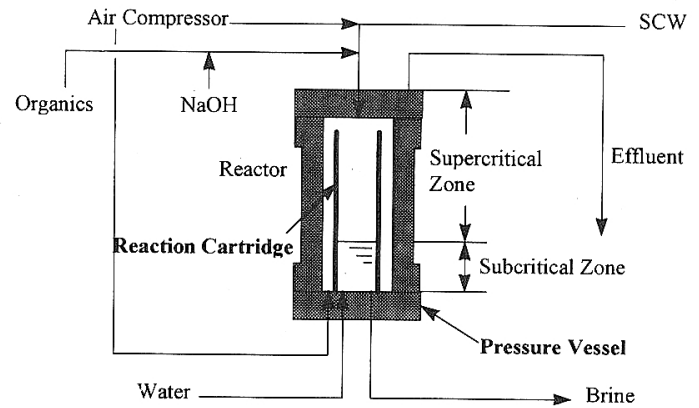

図 3 パイロットプラントの概略図（ベッセルリアク 夕一使用)
を 2 t/日で処理する能力がある。

分解対象物, 酸化剂 (空気), 中和郕 $(\mathrm{NaOH}) お$ よび超臨界水は縦型の円筒反応器上部より供給される。 反応器内上部の温度は, 分解対象物と酸化刘との反応 熱で， $600^{\circ} \mathrm{C}$ 前後まで昇温される。反応生成物である $\mathrm{CO}_{2}, \mathrm{H}_{2} \mathrm{O}$ は供給した超臨界水とともに, 反応器上 部より排出される。有機塩素化合物等の分解生成物で ある塩化物イオンは中和により無機塩を生じるが，こ の温度域では固形物として析出する。そこで, 反応器 の下部に，常温の水を供給し， $100^{\circ} \mathrm{C}$ 以下の水が存在 する領域を形成させる。固形物として析出した無機塩 はその温度領域で溶解し, 系外に排出される。反応器 内の温度分布を図 4 に示す。

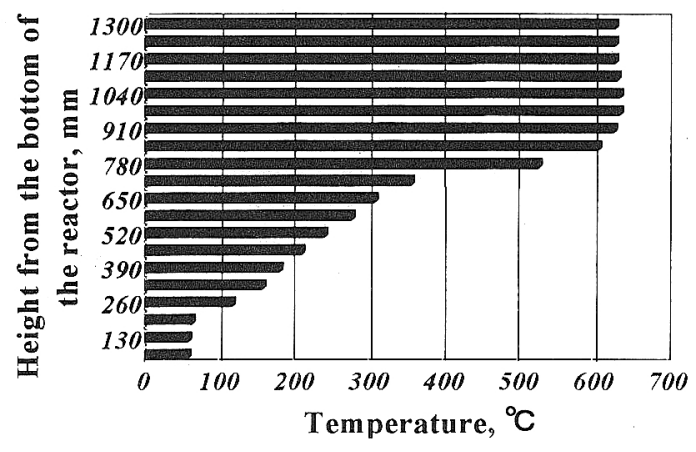

図 4 反応器内温度分布 


大 江 太 郎

表 3 DMSO 分解実験条件

\begin{tabular}{|c|c|c|c|c|c|c|c|c|c|c|c|c|}
\hline \multirow[t]{4}{*}{ Waste } & \multicolumn{10}{|c|}{ Supply } & \multicolumn{2}{|c|}{$\begin{array}{l}\text { Reaction } \\
\text { Condition }\end{array}$} \\
\hline & \multicolumn{3}{|c|}{ Organic compounds } & \multicolumn{2}{|c|}{ SCW } & \multicolumn{2}{|c|}{ Air } & \multicolumn{3}{|c|}{$\mathrm{NaOH}$} & \multirow[b]{2}{*}{ Temp. } & \multirow[b]{2}{*}{ Press. } \\
\hline & $\begin{array}{l}\text { Feed } \\
\text { Rate }\end{array}$ & $\begin{array}{l}\text { Waste } \\
\text { Conc. }\end{array}$ & $\begin{array}{r}\text { IPA } \\
\text { Conc. }\end{array}$ & $\begin{array}{l}\text { Feed } \\
\text { Rate }\end{array}$ & Temp. & $\begin{array}{l}\text { Feed } \\
\text { Rate }\end{array}$ & $\begin{array}{c}\text { Air } \\
\text { Ratio }\end{array}$ & $\begin{array}{l}\text { Feed } \\
\text { Rate }\end{array}$ & Conc. & $\begin{array}{c}\text { Stoichio } \\
\text {-metric } \\
\text { Ratio }\end{array}$ & & \\
\hline & $\mathrm{L} / \mathrm{hr}$ & $\mathrm{mg} / \mathrm{L}$ & wt $\%$ & $\mathrm{~L} / \mathrm{hr}$ & ${ }^{\circ} \mathrm{C}$ & $\mathrm{Nm}^{3} / \mathrm{hr}$ & - & $\mathrm{L} / \mathrm{hr}$ & wt $\%$ & - & ${ }^{\circ} \mathrm{C}$ & $\mathrm{MPa}$ \\
\hline DMSO & 18.6 & 12,538 & 47.5 & 95 & 600 & 120 & 1.9 & 1.1 & 25 & 1.2 & 566 & 24 \\
\hline
\end{tabular}

\section{5. 各種廃棄物に対する分解実験結果}

\section{1 硫黄系化合物：ジメチルスルフォキシド (DMSO)}

DMSO は極性有機溶媒として知られており, 半導 体工場などでは洗浄工程で用いられている。この DMSO $47.5 \mathrm{wt} \% \mathrm{IPA}$ 水溶液に混合し，上述のパ イロットプラントにより分解実験を行った。表 3，4 に実験条件と結果を示す。排出液中のDMSO と TOC を測定した結果，どちらも定量下限值以下であ った。また表には示していないが，排ガス中に $\mathrm{SO}_{2}$ は検出されなかった。

\section{$5.2 \mathrm{PCB}$}

PCB は現在ではその使用と製造が禁止されており， 現在は特定管理廃棄物として保管されている。処理が 滞つている最たる理由は, クローズド処理が難しく, 住民同意が得にくいということである。超臨界水酸化 では，水中での分解反応であるため，PCBのような 有機塩素化合物は，まず，高温の水により脱塩素化さ れ，中和により塩化ナトリウムとなり，その後，酸化 反応により，PCB を構成している炭素と水素はそれ

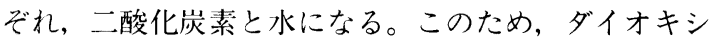
ンに代表される副生成物は発生しない。また，焼却と 違い，反応生成物は大気中に放出されず，水中に含ま
表 4 実験結果（DMSO）

\begin{tabular}{c|c|c|c|c}
\hline \multirow{2}{*}{ Waste } & \multicolumn{4}{c}{ Effluent } \\
\cline { 2 - 5 } & \multicolumn{2}{|c}{ DMSO } & \multicolumn{2}{c}{ TOC } \\
\cline { 2 - 5 } & Conc. & DRE & Conc. & DRE \\
\cline { 2 - 5 } & $\mathrm{mg} / \mathrm{L}$ & $\%$ & $\mathrm{mg} / \mathrm{L}$ & $\%$ \\
\hline \multirow{2}{*}{ DMSO } & $<0.01$ & $>99.999$ & $<0.5$ & $>99.99$ \\
\hline
\end{tabular}

れるため, 監視・回収が容易でり, クローズド的な処 理が行なえる。

PCB は試験のためにのみ用いることができるが, 試験により排出される液体は全量保管が義務づけられ ている。この制限のため，パイロットプラントではな くベンチスケールプラントにより実験を行なった。表 5 に実験結果を示す。

このように，高濃度（7 wt\%）の PCBであっても ダイオキシン類，コプラナ PCB といった副生成物を 生じずに分解が行なえた。

\section{3 下水污泥}

下水污泥の焼却に替わる処理の開発として, 現在, 日本下水道事業団と共同研究（H 8 10 年度）を行つ ている。下水污泥は乾燥污泥中に窒素が $5 \mathrm{wt} \%$ 近く 含有しているため, 窒素の分解が問題となる。図 5 に

表 5 PCB 分解結果

\begin{tabular}{c|c|c|c|c|c|c|c|c}
\hline \multirow{2}{*}{$\begin{array}{c}\text { Run } \\
\text { No }\end{array}$} & 反応前 & \multicolumn{2}{|c|}{$\mathrm{PCBs}$ 濃度 } & \multicolumn{2}{|c|}{ ダイオキシン類 } & \multicolumn{2}{|c}{ コプラナ PCBs } & PCB \\
\cline { 2 - 9 } & $\mathrm{PCB}$ 濃度 & 処理液 & 排ガス & 処理液 & 排ガス & 処理液 & 排ガス & 分解率 \\
\hline 単位 & $\mathrm{mg} / \mathrm{kg}$ & $\mu \mathrm{g} / \mathrm{L}$ & $\mathrm{ng}-\mathrm{TEQ} / \mathrm{m}^{3}$ & $\mathrm{ng}-\mathrm{TEQ} / \mathrm{L}$ & $\mathrm{ng}-\mathrm{TEQ} / \mathrm{m}^{3}$ & $\mathrm{ng}-\mathrm{TEQ} / \mathrm{L}$ & $\mathrm{ng}-\mathrm{TEQ} / \mathrm{m}^{3}$ & $\%$ \\
\hline $\mathrm{P}-01$ & 1,000 & $<0.5$ & $<0.5$ & $<0.012$ & $<0.05$ & $<0.012$ & $<0.05$ & $>99.999$ \\
\hline $\mathrm{P}-02$ & 10,300 & $<0.5$ & $<0.5$ & $<0.012$ & $<0.05$ & $<0.012$ & $<0.05$ & $>99.9999$ \\
\hline $\mathrm{P}-03$ & 70,000 & 0.6 & $<0.5$ & $<0.012$ & $<0.05$ & $<0.012$ & $<0.05$ & $>99.99997$ \\
\hline
\end{tabular}




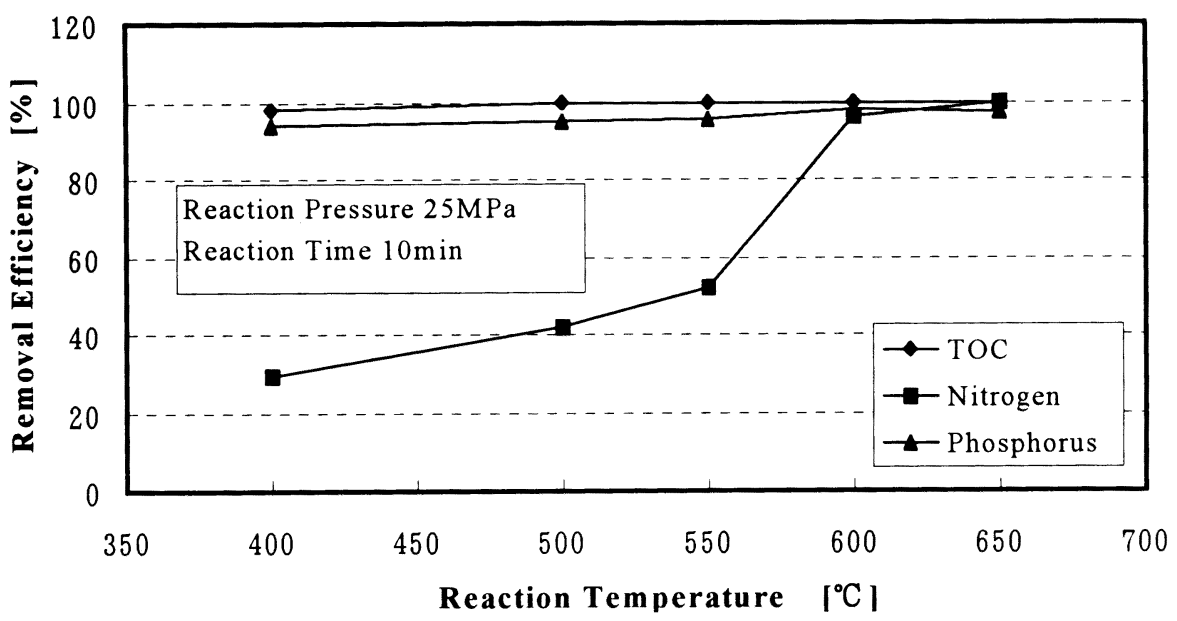

図 5 下水污泥の反応温度に対する分解特性

オートクレーブによるバッチ実験により得た反応温度 と分解率の関係を示す。ここで, リンの除去率は, リ ン酸塩として除去されたことを示し，窒素除去率は窒 素ガスとして除去されたことを示している。炭素およ びリンは実験を行った $400^{\circ} \mathrm{C}$ 以上であれば，反応温度 にかかわらず，良好な分解特性を示した。しかしなが

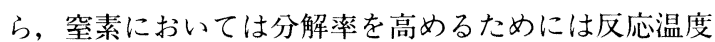
を $600^{\circ} \mathrm{C}$ 以上にする必要があることがわかった。
6. ペーパーミルスラッジの処理 (文献 8 より引用)

ペーパーミルスラッジ（繊維状細片，充填剂，皮膜 剂, 残存パルプ化学物質等) のような固形状廃棄物の 処理としては埋め立てが選ばれていたが, 将来の埋め 立て処理に対する規制強化を考えると, 狫却処理が最 も実用性が高いと考えられている。一方, ペーパーミ ルスラッジには有害物質である PCDD P PCDF が存 在するといわれており，このような物質を焼却処理し

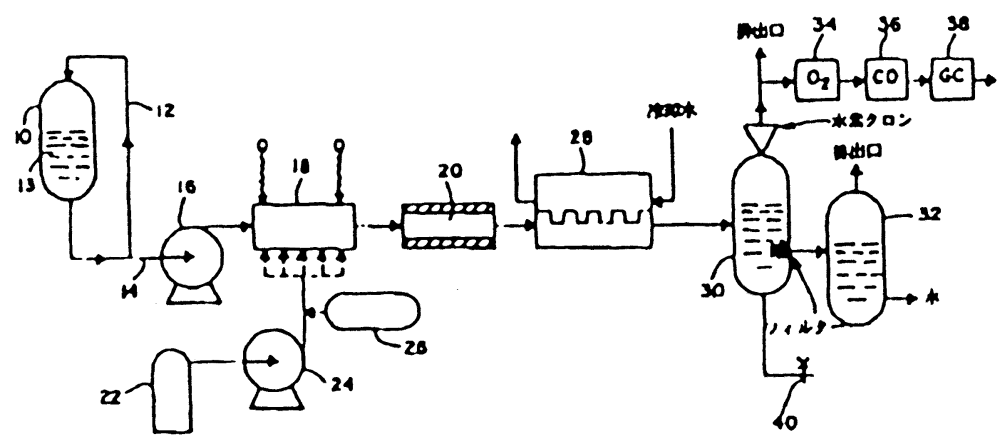

(付号の説明)

$\begin{array}{ll}10: \text { 原水タンク } & 26: \text { アキュムレーター } \\ 12: \text { 循環ループ } & 28: \text { 熱交換器 } \\ 14: \text { 給水ライン } & 30: \text { 分離タンク } \\ 16: \text { 高圧ポンプ } & 32: \text { 排水タンク } \\ 18: \text { ヒーター } & 34: \text { 酸素計 } \\ 20: \text { 反応器 } & 36: \text { 一酸化炭素計 } \\ 22: \text { シリンダー } & 38: \text { ガスクロマトグラフ } \\ 24: \text { コンプレッサー } & 40: \text { 固形物取出しロ }\end{array}$

図 6 実験装置困 
表 6 実験条件

\begin{tabular}{l|c|c}
\hline & 実験 $\mathrm{A}$ & 実験 $\mathrm{B}$ \\
\hline 反応器温度 $\left[{ }^{\circ} \mathrm{C}\right]$ & 520 & 520 \\
\hline 反応器圧力 $[\mathrm{MPa}]$ & 26 & 26 \\
\hline 全供給量 $[\mathrm{L}]$ & 17.4 & 16.0 \\
\hline 平圴供給流量 $[\mathrm{mL} / \mathrm{min}]$ & 73 & 33 \\
\hline 全固形分 (残さ) $[\mathrm{g}]$ & 44.8 & 30.2 \\
\hline 平均固形分流量 $[\mathrm{g} / \mathrm{Hr}]$ & 11.2 & 3.8 \\
\hline
\end{tabular}

表 7 実験結果

\begin{tabular}{l|c|c}
\hline & 実験 A & 実験 B \\
\hline $2,3,7,8-\mathrm{TCDD}[\mathrm{wt} \%]$ & 98.4 & $99.9 \sim 99.97$ \\
\hline 全 TCDD [wt\%] & 88.6 & $99.5 \sim 99.6$ \\
\hline $2,3,7,8-\mathrm{TCDF}[\mathrm{wt} \%]$ & 97.6 & $98.4 \sim 98.8$ \\
\hline 全 TCDF [wt\%] & 91.0 & $92.0 \sim 94.3$ \\
\hline
\end{tabular}

た場合の大気への拡散が危惧される。文献 8 はこのよ うな背景の基にペーパーミルスラッジ中のダイオキシ ンを超臨界水酸化により処理する方法として Kim berly-Clark 社から平成 3 年に出願されたものである (審查末請求)。図 6, 表 6, 表 7 にその特許の実施例 を示す。

<対象物>

実験 A：ペーパーミルスラッジ（固形物濃度 3.3 wt\%)

実験 B：ペーパーミルスラッジ（固形物濃度 1.65 $w t \%)+2,3,7,8$-TCDD (1,600 ppt)

\section{7. 結言}

超臨界水酸化は種々の有機物に対し, 高い分解特性 を亦すとともに排がス処理設備が不要という大きなメ リットを持ち合わせている。また，本文ではふれなか ったが, 高压下の処理であるため, 処理生成物として
の二酸化炭素を液化し回収するプロセスも考えられる。 二酸化炭素の排出量とダイオキシンに対する規制が強 化されることを考えると，超臨界水酸化は時代にマッ チした有力な処理技術の 1 つとなるだろう。

\section{参考文献}

1）長浜邦雄：“超臨界流体の最新利用技術（小林, 安芸編)”，テクノシステム (1986)，p 32

2）鈴木明：“超臨界水による有機物の分解” 水環境 学会誌, Vol.15 No.12 (1992), p 862-867

3）鈴木明，安生徳幸，川崎慎一朗，中村忠：“超臨 界水酸化法による PCBs 完全処理技術” PCB に 関する国際セミナー，Dec 2-4（1996）

4) Timberlake S.H., G.T. Hong, M. Simson and M. Modell; "Supercritical Water Oxidation for Wastewater Treatment: Preliminary Study of Urea Destruction", SAE Technical Papers \#820872, 12th Intersociety Conference on Environmental Systems, San Diego, California, July 19-21 (1982)

5) Thomason T.B. and M. Modell : "Supercritical Water Destruction of Aqueous Wastes", HAZARDOUS WASTE, Vol.1. No.4, P.453 (1984)

6) M. Modell : "Supercritical Water Oxidation", Standard Handbook of Hazardous Waste Treatment and Disposal, Edt. By H.M. Freeman, McGraw Hill, p.8.153 (1989)

7) Thomason T.B., G.T. Hong, K.C. Swallow and W.R. Killilea: "The MODAR Supercritical Water Oxidation Process", Innovative Hazardous Waste Treatment Technology Series, Vol.1: Thermal Process, Edt. by H.M. Freeman, Technomic Publishing Co., p.31 (1990)

8）特願平 3-263780 